\title{
Back to the Future for African Infrastructure? Why State-Ownership Is No More Promising the Second Time Around \\ By John Nellis
}

\begin{abstract}
Too many African state-owned enterprises (SOEs), particularly those in infrastructure sectors, have a long history of poor performance. African governments and donors labored through the 1970s and 1980s to improve SOE performance through "commercialization"-i.e., methods short of ownership change. These generally failed, giving rise, in the 1990s, to much more heavy reliance on private sector participation and ownership. This approach produced some successes, but Africa's private participation in infrastructure (PPI) initiatives have been comparatively few and weak. A number of those that have been launched have run into problems, to the point where both investor and African government interest in the approach has waned in the last few years. The reform is not popular-surveys of public opinion in 15 African countries reveal that only a third of respondents prefer private to stateowned firms. Nonetheless, African states (and their supporters) should not jettison the PPI approach. Rather, they should acknowledge its limitations, and recognize the large scope and moderate pace of the preparatory measures required both to improve their investment climates and to make PPI work effectively.
\end{abstract}

The Center for Global Development is an independent think tank that works to reduce global poverty and inequality through rigorous research and active engagement with the policy community.

Use and dissemination of this Working Paper is encouraged, however reproduced copies may not be used for commercial purposes. Further usage is permitted under the terms of the Creative Commons License. The views expressed in this paper are those of the author and should not be attributed to the directors or funders of the Center for Global Development. 


\title{
Back to the Future for African Infrastructure? Why State-Ownership Is No More Promising the Second Time Around
}

\author{
by \\ John Nellis* \\ Center for Global Development \\ Washington, DC
}

*The author wishes to thank Philippe Benoit, Ioannis Kessides, Michael Klein, Alan Townsend and Michel Wormser, all of the World Bank, and Nancy Birdsall of the Center for Global Development, for helpful suggestions on earlier drafts. This paper is based on a study funded by the Energy Sector Management Assistance Program (ESMAP) of the World Bank. A slightly different version was first issued as ESMAP Technical Paper 084, in November of 2005. Thanks to ESMAP for permission to issue this version of the paper as a CGD Working Paper. 
Table of Contents

1. Introduction \& Summary. ................................................

2. The Starting Point: Africa Opts for Socialism............................4

3. ....and this results in a comparatively large public enterprise sector......6

4. Poor Performance.............................................................7

5. Causes of Poor Performance..............................................8

6. Enter the IFIs..........................................................11

7. SOE Reforms Attempted: Commercialization...........................13

8. Results of the Commercialization Approach................................15

9. First Steps in Privatization...............................................17

10. The 1990s: Paradigm Shift to Privatization and PPI....................19

Part of a General Trend...................................................19

PPI in Africa.........................................................21

Results in General..................................................24

PPI Results in Sub-Saharan Africa......................................25

11. Conclusions...........................................................28

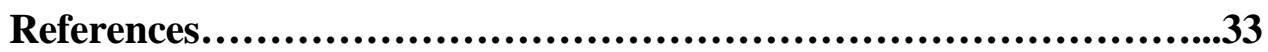




\section{Introduction \& Summary}

State-owned enterprises (SOEs) have featured prominently in the development strategies of most states in Sub-Saharan Africa (SSA). Far too many of these SOEs, and particularly those in infrastructure-energy, water and sewerage, telecommunications, transport-have a long history of poor performance. This situation had its roots in circumstances prevailing at the time most African states gained their independence, which led to the widespread adoption of statist, interventionist economic policies in the 1960s and 1970s. These origins are reviewed, together with the problems they caused, the corrective measures attempted back in the 1970s and 1980s, and the results of early reform efforts. The conclusion is that in this period African governments, with and without donor involvement, failed to reform state firms using evolutionary methods (often termed "commercialization" or "corporatization") short of ownership change. This failure gave rise to much more heavy reliance on private sector participation and ownership.

The altered approach is reviewed, focusing on its application in infrastructure from about 1990 to the present. The private-sector oriented reform strategy has produced some clear successes in Africa, as measured by increases in the quantity and quality of service offered, particularly in telecommunications. Most studies of private involvement in infrastructure conclude that performance improved, compared to what one could reasonably expect to have happened under continued public ownership and operation. Still, it cannot be denied that sub-Saharan Africa has comparatively weakly and somewhat reluctantly participated in private participation in infrastructure (PPI) initiatives. A number of those that have been launched have run into problems, to the point where both investor and African government interest in the approach has waned in the last few years. ${ }^{1}$ The reform is not popularsurveys of public opinion in 15 African countries reveal that only a third of respondents prefer private to state-owned firms.

So: The PPI approach has not, at least not yet, produced in Africa the massive investments and dramatically improved technical performance hoped for and still needed in transport, energy and water and sewerage. Is the solution to return to a strategy of improving state firms under public management? Any effort to reapply that strategy would have to overcome the many and serious problems encountered the first time around, revealed in detail below. The evidence suggests that this will be very hard to do. Moreover, African governments do not possess the massive financial resources required to renew and expand their infrastructure networks. And even a very large increase of "official" sources of infrastructure investment capital from the international financial institutions (IFIs) would not and could not bridge the gap. Only private capital markets can produce the sums required.

The conclusion is that African states (and their supporters) should not jettison the PPI approach - especially when, as is shown below, so few of them have really put it to the test. Rather, they should acknowledge its limitations, and recognize the large scope and

\footnotetext{
${ }^{1}$ And particularly after September, 2001, when many large infrastructure investors shifted their views concerning the risks and rewards of transactions in emerging and developing markets in general.
} 
moderate pace of the preparatory measures required both to improve their investment climates and to make PPI work effectively.

\section{The Starting Point: Africa Opts for Socialism²....}

The majority of Sub-Saharan African states came into existence in the 1960s, following struggles and negotiations with the colonial powers. At independence, most African governments inherited the notion that extensive public sector involvement in the economy was the natural, proper order of affairs. Colonial regimes, especially after 1945, had created and run economic planning agencies, agricultural marketing and stabilization boards, and industrial and infrastructure parastatal enterprises. They had instituted wage and price controls, and generally intervened in a large number of economic activities. Thus, most of the African leaders that came to power in the 1960s were accustomed to a high level of economic intrusion on the part of government.

Moreover, many if not most of the new African leaders were ideologically predisposed to government control of the economy's "commanding heights." In large part, this was because they saw a close link between liberal capitalism and colonialism and imperialism. The prevailing intellectual climate in the schools they attended and the circles they mixed in, at home and abroad, was leftist and statist; social democratic at least, and often more overtly "scientific" socialist. Africans who spent time in Europe, following World War II, noted the strong association between membership in left parties and organizations and opposition to colonialism.

Moreover, in the 1950s and 60s, academic circles within Africa, and on both sides of the Atlantic, espoused planning and a high degree of public intervention in markets to protect the public interest. Finally, a number of African intellectuals, reflecting on the many collectivist and community-oriented elements in their cultural heritage, concluded that socialism was more appropriate to African social circumstances. These ideas influenced the thinking of a number of African intellectuals from Sekou Toure and Leopold Senghor in the west of the continent, to Kenneth Kaunda and Julius Nyerere in the east. They, and many other African leaders, became convinced that planning and socialism were superior to unfettered markets, which they blamed for Africa's widespread poverty, ignorance and disease.

In addition, the examples of Russia and China influenced African leaders. These countries had achieved political unity - a preoccupation in African multiethnic states-and apparently were emerging rapidly from underdevelopment due to the power of the socialist approach. Their experiences fostered the belief that the solution to acute social and economic ills lay in managed, not free markets Nor did the outspoken anti-colonialism of the Communist bloc in international forums hurt the socialist cause; the stance was especially welcomed by Africans. In sum, government intervention in the economy was seen as the natural order of affairs by new African regimes.

\footnotetext{
2 This section draws on Nellis (1986).
} 
As a result, from 1960 through the early 1980s, at least 16 Sub-Saharan African countries designated their approaches as socialist, or on the path towards socialism. A nonexhaustive list includes Angola, Benin, Burkina Faso (at the time, Upper Volta), CongoBrazzaville, Ethiopia, Ghana, Guinea-Bissau, Guinea, Madagascar, Mali, Mozambique, Senegal, Sudan, Tanzania, Zambia and Zimbabwe. A number of other African states expressed general approval of a socialist approach without formally adopting one; and a few, such as Kenya, attempted to cloak what were obviously market-oriented policies in the garb of socialist principles. ${ }^{3}$ Socialism became the prevailing African ideology. Public ownership and management of productive entities, especially infrastructure, was its first operational principle.

Even where ideology was not a factor, or where the depth of the dedication to socialist principles was questionable, there were two compelling practical concerns that appeared to justify public intervention: The very small size and limited capital, and the generally nonAfrican nature, of local private sectors.

In most new African states the private sector was small, and more involved in commerce than production. Domestic business-people were mainly traders, brokers and merchants rather than large investors or industrial entrepreneurs. State intervention seemed justified by the embryonic or small-scale nature of the indigenous private sector. Regarding ethnicity, in many African countries immigrant communities-Asians in East and parts of Central Africa, Lebanese in a number of West African states - held the leading positions in the retail commercial sector in cities and towns and even in the rural areas. Regrettably, as elsewhere in the world, the presence of a non-native commercial minority spurred envy and resentment. A few leaders succumbed to the temptation to use this resentment for political ends; even the many that did not still felt obliged to take proactive steps to advance the economic interests of the black African majority. Planning and state-owned enterprises seemed to be the logical policy responses.

Leaders of developing countries, not only in Africa, were convinced that large-scale industrialization was, as the Algerians put it as late as 1975, the "remède unique aux problèmes de sous- développement,” (Algérie Presse Service, 1975). They concluded that public enterprises were the solution to the questions of both scale and nationality. It was believed that state-owned and operated firms would aid technology transfer in fields that were supposedly strategic, in industry and infrastructure. A number of development economists suggested at the time that publicly owned firms would be better-i.e., more rational and socially beneficial—investors, that they would fill "entrepreneurial gaps," gain access to international concessionary and commercial credit denied to small local businesspeople, provide services the private sector either would not or could not (or even, to some, should not), and generally serve as training centers where Africans would acquire the technical and administrative skills required in a modern economy (see, for example, Killick, 1981: chapter 11). The point is that in the 1960s and 70s a number of plausible theoretical justifications for public enterprises were in the air, lending respectable economic support to what governments in Asia, Latin America and Africa were strongly predisposed

\footnotetext{
${ }^{3}$ See, for example, Government of Kenya, African Socialism and its Application to Planning in Kenya (Nairobi: Government Printer, 1965).
} 
to do for social and political reasons. Nor can one discount the fact that state intervention in productive entities provided a number of highly lucrative perks and rents to the inheriting elites, almost none of whom had extensive private sector backgrounds, ties or personal wealth.

\section{3.....and this results in a comparatively large public enterprise sector}

With these motivations and rationales, after independence many African states embarked on the creation of state-owned and operated firms. In the more ideologically committed states-Ethiopia, Sudan, Tanzania and Zambia-expropriation was applied in key sectors. Tanzania, for example, nationalized a number of industries and agro-industrial estates in 1967 "to ensure the proper management of the commanding heights" of the economy; "to transform the economy by articulating the principles of socialism and self-reliance;" and to promote income and regional equity. (Msambichaka and Bagachwa, 1984: 384) Since most African states started with state-owned infrastructure sectors, nationalization of such firms was usually unnecessary. It did happen: Senegal, for example, in 1971 nationalized the privately leased and managed urban water system it had inherited at independence.

There are great gaps in the data, but it is estimated that by the end of the 1970s the average African country's public enterprise sector accounted for over 17 percent of GDP, compared to a worldwide average of about 10 percent (falling to 5 percent in OECD countries). Of course, there was great variation among African countries, with the more dedicated or overt socialists and nationalizers having the largest state sectors, with others-Botswana, Liberia and Sierra Leone, for example-well below the average. However, in line with close to universal practice at the time, all African countries, socialist or not, held most or all of their infrastructure services in public ownership and operation.

Other measures from a number of African studies and surveys in the 1970s and 80s show the economic importance of state-owned enterprises (henceforth SOEs):

- SOEs accounted for about one-quarter of total formal sector employment in all reporting African countries, and more than 18 percent of all non-agricultural employment; ${ }^{4}$

- $\quad$ SOEs accounted for more than 20 percent of gross domestic investment;

- more than 14 percent of total external debt, and

- more than one-third of domestic credit.

- In 15 of 22 francophone African countries surveyed, SOEs ranked first in sales. Clearly, Sub-Saharan African states relied heavily on SOEs to achieve their economic objectives.

\footnotetext{
${ }^{4}$ Compared to, at the time, 4 percent in OECD countries, 15 percent in Asia, 5.5 percent in Latin America and 10 percent in reporting North African countries (source: Nellis, 1986, 10).
} 


\section{Poor performance}

From the outset SOE financial and economic performance generally failed to meet the expectations of their creators and funders. This was not universally the case; in most African countries in the period 1965-80 (and beyond) there were SOEs that performed, at least for a time, adequately and sometimes very well, by the most stringent of standards (e.g., Ethiopian Airlines, the Kenya Tea Development Authority, Sierra Leone's Guma Valley Water Company). But the good performers were heavily outnumbered by the bad.

Consider the case of Kenya, ${ }^{5}$ where in 1982 the Government estimated the annual average rate of return on the $\$ 1.4$ billion (1981 dollars) invested in SOEs since independence, in 1963 , to be 0.2 percent_—a barely positive return greatly less than what could have been obtained by depositing the sum in an interest-bearing account. Moreover, the slightly positive overall rate of return was due to the good performance of a few profitable firms. Most SOEs, especially crop marketing boards in the agricultural areas on which the bulk of the population depended for their livelihood, persistently ran large losses (and provided a poor quality of service). In addition, Kenyan investigators found little evidence that the SOEs were producing a level of social benefits-increased employment, improved income distribution, contributions to regional equality, technology transfer and management training - that might have offset or justified the investment, and that a number of apologists cited as reasons to overlook the poor financial performance. In several cases where it was claimed that such benefits were being produced, the point was asserted rather than demonstrated.

Aggregate data were not produced in this period, but bits and pieces of information cumulatively mounted to a damning indictment of SOE performance continent-wide. For example, in twelve West African countries, 62 percent of surveyed SOEs showed net losses, and 36 percent were in a state of negative net worth. (Bovet, 1985) By the end of the 1970s, cumulative SOE losses in Mali amounted to 6 percent of GDP. A 1980 study of eight Togolese SOEs revealed that losses in this group alone equaled 4 percent of GDP. In Benin, more than 60 percent of SOEs had net losses; more than three-fourths had debt/equity ratios greater than 5 to 1 ; close to half had negative net worth, and more than half had negative net working capital. (Grosh and Mukandala: 1994, 17) A 1985 survey of transport sector SOE performance in 18 francophone African countries found that only one-fifth generated revenue sufficient to cover operating costs, depreciation and financial charges. Another fifth covered variable costs plus depreciation but not finance charges; a further 40 percent covered only operating costs, while the final fifth were not even covering these. (World Bank, 1985: 36,7) While few other economic studies undertaken in this period singled out infrastructure SOEs, their relatively large economic and financial size, and additional anecdotal evidence, suggest that they were major contributors to the low level of general performance.

\footnotetext{
${ }^{5}$ Though Kenya was far from socialist it still amassed a large and important SOE sector, comprised, by 1984, of 176 commercial or semi-commercial enterprises and a further 147 statutory boards. These SOEs accounted for 8 percent of GDP, 55 percent of public sector capital formation, 31 percent of public and 15 percent of total formal employment.
} 
In a great number of African countries the financial burden posed by poorly performing SOEs, particularly those in infrastructure, caused macro-fiscal problems. In addition, the often inadequate quantity and poor quality of infrastructure services was annoying (and in the case of poor quality water, dangerous) to regular customers, and raised costs and discouraged investment in the private sector. Consumers across the continent had to wait years for phones or to obtain connection to the electricity grid; outages were frequent and prolonged; the wait for repairs was lengthy; bribes - that could be very large-were usually required to obtain a connection or a repair; public transport was often expensive, always overcrowded and unreliable, and sometimes unsafe. A large percentage of private African firms could not (and still cannot) ${ }^{6}$ depend on publicly provided infrastructure services and were forced to invest in high-cost alternatives; i.e., electric generators, wells, road-building and maintenance, the stringing of their own telephone lines, etc.

\section{Causes of poor performance}

Many studies of this period looked into the causes of poor SOE performance. The diagnosis was that the fundamental problem of SOEs, in infrastructure as well as manufacturing, was multiple and conflicting objectives. Government owners decreed that their SOEs operate in a commercial, efficient and profitable manner, and at the same time insisted that they provide goods and services at prices less than cost-covering levels, serve as generators of employment, receive their inputs from state-sanctioned suppliers, choose plant location on political rather than commercial criteria, etc., etc. The mixing of social with commercial objectives inevitably led to political interference in operational decisions to the detriment of managerial autonomy, commercial performance, and economic efficiency. The syndrome manifested itself in:

- Poor initial investment decisions: This factor applies more to industrial and commercial than to infrastructure SOEs. Examples include Niger's uranium producing SOE, where planners assumed that the historically high mid-1970s market price for uranium would persist indefinitely (it did not); a textile SOE in Benin relying heavily on unfettered exports to Nigeria (the Nigerians closed the border to textile imports); a banana-boxing, for export, SOE in Somalia which had a breakeven production level higher than national banana production (the anticipated increase in production never occurred); a SOE shoe factory in Tanzania (supported by the World Bank) that never exceeded 4 percent of rated production; etc. The African landscape became littered with SOEs producing at a fraction of rated capacity, generally incurring large losses, and failing to service the debts incurred in their creation. Risky investment decisions are, of course, an inescapable part of doing business. A critical problem with SOEs in Africa (and elsewhere) is that SOE managers lacked the flexibility and autonomy to respond to shifting market conditions. Their government owners would not allow them to cut costs by shedding labor, closing plants, dropping or adding production lines, changing suppliers, etc. The problems of poor initial

\footnotetext{
${ }^{6}$ World Bank "investment climate" surveys in 8 SSA countries, dating from 2003-4, indicate that almost half of private firms surveyed had installed generators to provide power during outages.
} 
investments were greatly compounded by a pronounced lack of managerial agility.

- Inadequate capitalization: Few African governments were able to endow their SOEs with proper levels of initial and working capital, forcing them to rely heavily on debt to finance basic operations. This was imprudent, expensive, and, in infrastructure, harmful to network expansion to serve unmet demand. As direct government transfers to SOEs of all sorts declined greatly in the 1980s (due to internal financial problems and external pressure from the IFIs, discussed below), SOEs turned to borrowing from the banking sector, itself largely state-owned at the time. Costs mounted, non-payment of debts multiplied, and SOEs sunk deeper and deeper into financial problems. In addition, the channeling of most commercial bank credit to SOEs (e.g., 80 percent in Senegal in the 1980s) "crowded out" loans to private firms.

- Below-cost pricing: This was a critical shortcoming in infrastructure SOEs. For social reasons, most African governments either set initial infrastructure tariffs at less than cost-covering levels, or failed to raise the tariffs as costs increased over time, or both. Low prices were justified on the grounds they helped poorer consumers afford essential services such as water and electricity. In reality, only a tiny fraction of African populations were linked to infrastructure formal distribution systems; these served only the urban areas, and mainly the commercial, official and elite residential sections of these urban areas. The principal beneficiaries of below-cost pricing were, and are, the comparatively well-off. Moreover, as noted, low revenues starved the infrastructure firms of the capital needed to expand into unserved areas.

- Collection deficiencies: Collection failures have plagued African infrastructure SOEs. The major delinquents have been government ministries and agencies, including other SOEs. Few SOEs have been able to cut service to non-paying clients, particularly government agencies. Infrastructure SOEs (and industrial ones as well) often reacted to the financial strain by failing to pay due taxes, customs duties, debts to state-owned banks and suppliers, contributions to social security systems, etc. This resulted in a cascading series of unpaid cross-debts, eroding discipline throughout the financial system.

- Poor reporting systems: A critical deficiency was inadequate financial reporting and monitoring systems: that is, weak or non-existent accounting at the level of the firm, and insufficient monitoring and follow up of firm and sector results by government reviewers and auditors. In Tanzania, for example, a 1988 study noted that, over time, about 1/3 of the country's 425 SOEs failed to produce basic accounts. Of accounts actually produced, $3 / 5$ were normally judged as "deficient" by the national auditor. Of the minority of 112 SOEs that generally submitted non-deficient accounts, $1 / 4$ ran losses. The upshot was that only 84 SOEs - 18 percent of the sector — could be judged as generally profitable. (Nellis, 1988, 17) The same report noted that only a handful of Tanzanian SOEs carried out regular inventories of assets, and there were few 
signs of control of cash, credit, procurement, or financial relations with subsidiaries. All this despite (perhaps because of) the existence of an astonishing 19 separate levels of supervision and control of SOEs, from workers councils, management committees, general managers and boards of directors within firms, through reviewing holding companies, parent, and several other technical ministries, beyond to the Commission of Public Investments in the Treasury (Ministry of Finance), to a variety of specialized bodies such as the Tanzania Audit Corporation, the Standing Committee on Parastatal Organisation (SCOPO), the single party's Standing Committee on Parastatals, a Parastatals Organisation Committee in Parliament, and periodic interventions by the National Price Commission, the Registrar of Companies, the National Productivity Council, etc. etc.

- Deficient Boards of Directors: In theory, Boards of Directors represent the interests of the shareholders of a firm; they are the first line of an owner's defense. Boards were constituted in a large percentage of African SOEs; but they generally failed to perform the functions of policy-makers, performance evaluators, supervisors of management and buffer between government and the SOE. Why? At the heart of the problem lay the issue of misplaced and inadequate incentives for both the representatives of the principal and the agents. Statutes often called for Ministers to hold seats on boards; in reality Ministers usually found more important things to do and SOE boards tended to be made up of middle-level civil servants, few with relevant technical or commercial experience. Typically, the same civil servants would sit on several or indeed many boards, diluting their already modest capacity to monitor corporate events. The implicit role of board members became to protect the interest of their ministry, a task often at odds with advancing the welfare of the SOE. Seldom, if ever, did African boards have any role in the selection of management. "Boards do not ensure managements achieve set targets of performance. Even where targets are set, weak boards often accept inadequate explanations from the managements for shortfalls in performance." (Tanzania Audit Corporation, 1986, 15) Board members often received fees and "sitting allowances" for attending meetings; board membership was used to reward political cronies, retiring generals, and MPs.

- Other shortcomings: Many SOE managers were untrained and owed their posts to political connections rather than technical skills. A number of them, in the absence of close and effective monitoring, used the firm's resources for personal or familial enrichment. Many African (and European, Asian and Latin American) politicians and public officials have reaped material and prestige benefits from SOEs, in the form of loans, gifts, transport, housing, board memberships, future jobs for themselves, present jobs for friends, relatives and supporters, procurement kick-backs, and much else. Domestic private sectors often have cozy supply relationships with SOEs that could be threatened by the arrival of more aggressive, quality-conscious, cost-cutting private owners. Thus, weak management was as much caused by the 
dysfunctional general system as it was a cause of it. It required exceptional managerial competence and personal devotion to overcome the many and severe policy and political obstacles to good performance. SOE managers were seldom given the resources and incentives and above all the autonomy to lead; they were rarely punished for poor practice and even less often rewarded for good; they spent endless hours in meetings in reviewing agencies and ministries in which discussion was interminable and decisions were rare. In sum, SOE managers possessed autonomy in areas where they should have been closely monitored - on most matters of financial reporting - and they generally lacked decision-making power where it was needed-concerning day-to-day operational matters.

In many African countries, a common scenario was as follows: Government failed to monitor SOE performance, or failed to act on the information it received. SOE losses mounted, and were covered through direct transfers from the budget and through indirect subsidies (e.g., as noted, the non-collection in SOEs of taxes, duties, social security payments, and later, bank loans; the tolerance of arrears to suppliers and utilities). By the late 1970s the African SOE financial situation was alarming, and by the early 1980s, critical. Almost everywhere in SSA the poor financial performance of SOEs became so burdensome to government budgets that it grew to be an obvious and major part of a "financing gap"— thus attracting the attention of the International Monetary Fund and the World Bank (the IFIs).

\section{Enter the IFIs}

Well prior to the recognition of SOEs as an aggregate problem area, the World Bank had been involved in lending to individual African utilities, in energy, transport and water and sewerage. In consequence, some technical and managerial capacity had been installed, and some financial and operational improvement occurred. Results however were piecemeal and modest; broader and more sustained attention was required.

The IFI response was first, to analyze the problem in greater detail; second, to assist African governments in setting up monitoring methods and agencies to obtain and act on performance data (and tabulate and settle the cross-debts which were particularly troublesome for infrastructure SOEs, usually situated at the end of the payments chain); and third, to include conditions in loans requesting and requiring the borrowing government to take policy and institutional steps to correct the performance problems.

The recognition of the magnitude and depth of African SOE problems coincided with the launching, in 1979, of the World Bank's "structural adjustment" lending operations. These operations differed from the Bank's traditional bricks and mortar projects that built dams, roads, schools or airports. Adjustment loans provided large resource injections in return for which the borrower committed to taking measures designed to correct unstable "imbalances" in the economy. ${ }^{7}$ Invariably, the recommended measures involved

\footnotetext{
${ }^{7}$ These imbalances could be brought about by unforeseen external "shocks;" e.g., rapid rises in energy prices, or by internal problems such as collapse of an export market.
} 
"reductions in expenditures to bring about an orderly adjustment of domestic demand to the reduced level of external resources available to the country.” (World Bank, 1991, 11) Since financial losses in African SOEs, especially infrastructure SOEs, tended to be substantial, they became a natural focus of the adjustment process. ${ }^{8}$

Adjustment loans and credits disbursed very rapidly. This gave participating governments quick access to badly needed foreign exchange, ostensibly to deal with balance of payments problems. The policy changes agreed upon ${ }^{9}$ could often be signed into existence just as quickly; but their implementation required institutional and behavioral change that was at least of a medium- and often of a long-term nature. To deal with these structural or institutional needs, adjustment operations were frequently accompanied by longer-term technical assistance operations furnishing borrowers with the expertise and training required. So, policy shifts were addressed in the "conditions" of the adjustment loans and credits, while the parallel technical assistance operations attempted to analyze and correct the informational and institutional deficiencies. (Henceforth in this study, "adjustment" refers to the actions requested and required in both types of loan or credit.)

From 1979 to 1989, the World Bank ${ }^{10}$ approved 51 structural adjustment operations with SOE-related components. SOE issues were also addressed in an additional 47 "sectoral adjustment operations," that is, loans and credits focusing on a single area or a few key economic problems. A few of these were specific to the SOE sector and were called PERLs; public enterprise reform loans. (Nellis, 1989b, 3-4) Many countries received more than one adjustment loan or credit in this period. Turkey alone, for example, took on five full adjustment and two sectoral operations. In total, the 51 structural adjustment operations through 1989 went to 34 different countries, and the 47 sectoral operations went to 31 different countries.

Africa was heavily represented in these SOE-related adjustment operations: 18 different African countries received 27 of the 51 structural mechanisms, and 15 different African countries received 24 of the 31 sector operations containing SOE components. There was considerable overlap in the two groups, but six African states received only sectoral credits. This raised to 24 the number of African countries receiving adjustment loans or credits containing SOE components. In sum, African cases accounted for 70 percent of the SOErelated adjustment universe in the 1980s. What was attempted, with what results?

\footnotetext{
${ }^{8}$ The World Bank's first explicit African SOE correction program began in Senegal, in 1976. The mounting data on poor SOE performance, and the budgetary burdens posed by this performance, contributed to the development of adjustment lending.

${ }^{9}$ All participating governments issued, at the beginning of each adjustment operation, a "letter of development policy," specifying major problems and stating the corrective steps they would take in the course of the operation. In many cases, particularly in low income countries, these were almost entirely drafted by Bank staff. True, the policies were always discussed with borrower government officials. Still, in Africa, local "ownership" of the required policy shifts was usually limited to a few convinced officials in the borrowing country's financial institutions; i.e., the central bank and the ministry of finance.

${ }^{10}$ Focus is on the World Bank because of (1) the availability of data and (2) the fact that at this point in time the IMF left structural changes to the World Bank. The expansion of IMF conditionality into such details came later.
} 


\section{SOE reforms attempted: Commercialization}

African SOE adjustment components in the 1980s centered on: operational analysis and information production, financial measures in and outside the enterprise to stem the flow of SOE sector losses, a wide range of restructuring and performance improvement measures not involving ownership change, the closure and liquidation of some loss-making commercial (not infrastructure) firms, and the preparation for-and in some cases, the carrying out of-privatization.

Requested $^{11}$ specific reforms included:

- classification studies to examine the proper role of the state and categorize the country's SOE portfolio into those to be retained, restructured, sold or closed (this led to considerable discussion and debate on the definition of a strategic SOE);

- the elimination of SOE monopolies and monopsonies;

- legal and legislative reforms aimed at making SOEs more corporate in nature, rationalizing control procedures, increasing managerial autonomy, altering the form, duties and responsibilities of Boards of Directors, etc.

- shifts in pricing formulae; i.e., specification of the method of determining infrastructure service tariffs, including when and how prices should be reviewed and altered;

- studies and actions on labor policy; through the support of studies determining the level of overstaffing, the creation and funding of severance pay mechanisms, training and redeployment schemes, and calls for retrenchment in specific firms or across the SOE sector;

- rationalizing SOE financial systems through arrears settlement efforts, reducing automatic or concessionary access to credit, strengthening the scrutiny of SOE expenditure and borrowing, strengthening internal accounting and external reviewing, and creating a level financial playing field between SOEs and private firms;

- creating or reinforcing SOE monitoring bodies; an activity heavily supported by technical assistance personnel;

- closing persistently loss-making commercial SOEs; ${ }^{12}$

- privatization, or the preparation for privatization, of a SOE or a set of SOES, again, in this period, almost all commercial in nature, and none in infrastructure.

Some examples: In multiple adjustment operations in Ivory Coast the principal SOE conditions were to set up financial reporting systems and establish monitorable indicators of management efficiency and enterprise productivity. "Extended actions" in the parallel TA loans included "reductions in real transfers to public enterprises," extension of a financial and performance reporting system to 31 major SOEs, the "rehabilitation of five

\footnotetext{
${ }^{11}$ In all approved adjustment operations the conditions were agreed to by the borrowing government-but that does not mean they were actually adopted.

${ }^{12}$ Closure and liquidation of a non-profitable commercial SOE was a condition of adjustment in Benin, Burundi, the Central African Republic, Guinea, Niger and Senegal.
} 
enterprises, audits of three, improvements of supervisory procedures in four." (World Bank: 1991, 291) All the major infrastructure SOEs were in the list of 31.

In Ghana, the focus was on cutting costs in the sector, mainly through payroll reductions. However, the bulk of this reduction was accomplished by removing 25,000 non-existent "ghost workers" from the payroll of the Cocoa Board, a promotion and marketing SOE for the country's main cash crop and export. (World Bank: 1991, 317) Other measures aimed at reviewing the qualifications and competence of managers in infrastructure SOEs, and studying and improving management procedures.

In Senegal the thrust of adjustment-supported reforms was improving SOE performance. From 1981 through 1988 a key feature of Senegalese SOE reform was the "contract-plan;" a theoretically binding, three to five year agreement setting out the mutual rights and responsibilities of the state-as owner and principal of the firm-and management, the agent. Detailed contract-plans were signed in nine different Senegalese SOEs including the infrastructure firms in transport, electricity, water, telecommunications, post and ports. In these contract-plans, government committed to a tariff regime and specified the conditions under which tariffs could be changed, and by how much; promised to provide the firm with stipulated investment resources; engaged to pay off existing arrears and to enforce policies preventing the re-emergence of arrears, and to limit government involvement in the firm to the specific areas and modes established in the document. The idea was to increase the autonomy of management to correctly guide the firm, enhance efficiency in the use of resources, and minimize-or explicitly compensate the firm for-non-commercial objectives. In return, SOE management committed to fulfilling a set of performance indicators leading to improved service quality and, often, expanded service quantity; meet investment timetables, and cut costs (most often by eliminating superfluous labor). Contract-plans of this type were installed in 11 SSA countries in addition to Senegal: Benin, Burundi, Congo, Cote d'Ivoire, Gambia, Guinea, Kenya, Madagascar, Mali, Niger and Nigeria. ${ }^{13}$

Two summary points: First, while even at this relatively early date there was a strong emphasis in adjustment conditionality on liquidation, lease or sale of seemingly hopeless SOEs, ${ }^{14}$ four of every five SOE conditions aimed at performance improvement through various forms of commercialization, not sale. Second, where closure or privatization was a condition of adjustment, it usually applied to commercial and manufacturing SOEs, not those in infrastructure. Private sector management or financing in an infrastructure SOE was now and then requested, but in no case was outright divestiture or even the lease of an infrastructure firm a matter of conditionality.

\footnotetext{
${ }^{13}$ In the countries italicized, contract-plans were installed as a result of World Bank adjustment operations.

${ }^{14}$ One attempt to quantify the strength of the preference looked into the details of SOE reform in the 1980s in 9 adjusting countries, five of them in SSA. Of the 143 individual SOE reforms reviewed, 21 dealt with the closure or lease or sale, full or partial, of a SOE. An additional 8 conditions called for the preparation for privatization without demanding the actual sale. Taken together, these measures made up 20 percent of all conditions, the single largest category. (Other actions most often called for dealt with pricing issues, reforms in the institutional framework, restructuring of a specific firm [usually an infrastructure firm], reductions in the workforce, and financial audits of troubled companies. [Nellis: 1989b, 15])
} 


\section{Results of the commercialization approach}

Price increases in SSA infrastructure SOEs proved relatively easy to implement. Monopoly providers were seldom averse to raising their revenues, so there was little or no opposition from firm managers. Since many government agencies had seldom paid the old tariffs, and doubted that they would be forced to behave differently in the future, increases rarely raised intense opposition from within ministries. Only those consumers who could not evade payment were discontent, since service quality did not often immediately rise in tandem with higher prices. The overall financial impact on the flow of funds was not as great as had been anticipated, due to the continuing non-payment of major clients, and the reluctance of many governments to do more than sanction a one-time price increase. The letter of the conditionality was often met (sometimes not even that), but the spiritinstitutionalizing a tariff system based on marginal costs for infrastructure providers, that would react to systemic changes such as inflation—was rarely pursued.

The easing of budgetary burdens was also accomplished quickly, at least on paper. Edicts ending government subventions were enacted. In many adjusting African countries, direct transfers from government budgets fell greatly and rapidly. Yet again, there was a "but:" The ending of loss-covering direct transfers left many SOEs in dire need of working capital, which they obtained from the state-owned banking system-with the explicit or implicit approval of government. In effect, the shutting off of a direct resource flow from one government-controlled tap was matched by the opening of a second, less direct, but still government-influenced faucet. In many countries, therefore, the decline in the official government deficit was matched or even exceeded by increases in indirect flows, and increases in the "quasi-fiscal deficit."

A fair amount of staff reduction took place in African SOEs, but the pace was slower and the financial impact less than anticipated. Few could complain about the elimination of "ghost" workers, and tighter reporting and monitoring systems led to some substantial reductions in these. However, opposition to the retrenchment of existing workers was substantial. The affected workers were visible, organized and vocal; their plight and protests raised the sympathies of many in Africa beyond workers and unions, from journalists and academics to civil servants and politicians of all sorts-usually including many in the enacting government. Lay-offs were deeply unpopular. They raised the political temperature and contributed to the rising public antipathy in Africa towards adjustment and the World Bank. Even when outright opposition was muted, retrenchment could and did encounter problems: Ghana's program of SOE workforce reduction, for example, was stopped as government realized it could not afford, even with World Bank loans, the extremely generous severance packages previously negotiated with public sector unions. In Niger, Zambia and elsewhere a number of workers were dismissed from SOEs, but many of those laid off found their way back into public employment in other SOEs, ministries or government agencies. Overall savings in the public sector wage bill tended to be modest.

Most disappointing were rehabilitation and restructuring efforts in SOEs. Under pressure from donors, government could and did commit to drastic and sometimes socially painful 
restructuring, including price hikes and layoffs. But the reforms often were not sustained; back-sliding was common. Governments would commit in principle to behavior change on which they could not or would not follow through.

The experience of Senegal illustrates the issue: By the end of the 1980s its SOE reform program had been underway for over a decade; it had been heavily supported by donor programs; and it had attempted comprehensive performance improvement measures through the contract-plan approach. Despite all this, the financial performance of the sector continuously declined in this period, with aggregate losses in SOEs almost doubling between 1982 and 1986, the peak years of the reform effort.

Hopes had been high for the contract-plans since they addressed the issues analysts had most often cited as problematic: In them, the commercial aims of SOEs were given priority, the mutual responsibilities and obligations of the two contracting parties were clearly specified, and precise performance measures, and the means by which they would be evaluated, were established. Tariff regimes were specified, investment programs determined, operations costed out and subsidies and compensation for non-commercial objectives imposed by government established.

But in many cases, the Government of Senegal proved unable or unwilling to honor the obligations it had made in the contract-plans, particularly the financial commitments. Tariff hikes called for in a contract-plan were later rejected by government. Commitments for government agencies to pay utility bills were not honored. Promises to make investment capital available to infrastructure SOEs were not kept. Managers attempting to cut costs, in line with the terms of the contract-plans, were forbidden by government superiors to fire workers, cut off service to delinquent customers, change suppliers, etc. Almost all the contract-plans had to be extensively and repeatedly revised, and many fell into abeyance. (Nellis: 1989b, 23-4)

The problem was that, despite the name, the agreements were not contracts in any binding sense. Government could, and did, ignore with impunity the terms of the agreement; managers had no legal recourse to force government to honor its obligations. (Nellis: 1989a, 77-8) As this became clear, the impact of the approach diminished. For example, in Congo (Brazzaville), 10 of the 18 contract-plans devised were abandoned in process. In Senegal, second-phase contract-plans tried to correct the problems by linking the plan period to the budget cycle, setting up high-level implementation committees to pressure and cajole government to meet its obligations, presenting alternative scenarios of performance, financing and pricing rather than stipulating one path only-but none of it worked; the revised contract-plans too failed to resolve the key issue of non-payment of utility bills by government departments. (Nellis: 1989a, 44) The mechanism continued to be applied, particularly in francophone Africa, up until the mid-1990s. But overall, this seemingly promising device, on which so much African government and donor resources were expended, produced few lasting results. 


\section{First Steps in Privatization ${ }^{15}$}

As disappointment mounted with SOE reform and rehabilitation measures, donor enthusiasm grew concerning privatization. In retrospect, this enthusiasm appears to have been generated as much or more by deep frustration with performance improvement approaches other than divestiture, and by expectations based on theory, rather than on hard empirical evidence of the superiority of private participation and ownership in the African setting. True, past SOE reforms not involving the private sector were deeply dissatisfying, and often the explanation was the incapacity of government owners to do or to sustain what needed to be done. Equally true, the theoretical advantages of private participation were considerable. Still, the shift to privatization was something of a leap of faith.

Nonetheless, in the 1980s, privatization of SOEs took place in a number of African statesincluding Senegal, Niger, Kenya, Ghana, Cote d'Ivoire and Guinea-and was called for by the IFIs in a number of others. In very few African cases was the decision to privatize totally home-grown or strongly endorsed or supported by domestic decision- and opinionmakers. While African proponents of privatization could be found, the main impetus for divestiture came from the donor community in general, and the IFIs in particular. To repeat, these early divestitures were relatively few in number, and concentrated in commercial-manufacturing, not infrastructure SOEs.

One tabulation calculated that worldwide, in the period 1980 through 1988, the World Bank concluded an average of 10 operations per year in which privatization featured prominently. (World Bank: 1992, 33) Slightly more than half of all these operations went to African countries. A reasonable estimate, therefore, is that about five World Bank loans per year in this region explicitly called for privatization measures in the 1980s.

The lessons of early privatization experience were several:

1. Liquidations, especially of defunct, non-functioning SOEs, proved comparatively easy to enact; ${ }^{16}$

2. SSA governments negotiated hard to buy time before a privatization decision was implemented; e.g., by agreeing to studies, preparation periods, the creation and staffing of privatization agencies, etc., all of which, it was plausibly argued, had to precede privatization, and all of which took more time to execute than had been planned;

3. Management contracts and leases were easier to implement than outright sales;

4. Joint ventures and sales of minority stakes were more readily accepted and could be put in place faster than transfers of a majority of equity;

5. Sales to non-nationals, or even to citizens of non-African ethnicity, consistently raised difficulties and moved slowly, if at all; and

\footnotetext{
15 "Privatization" here refers to a range of actions involving the private sector in the management, financing and ownership of a SOE, from management contracts, through leases and concessions, to the transfer of a majority equity stake to a private owner.

16 Though these could drag on interminably; e.g., in Kenya the Uplands Bacon SOE was in receivership for at least 14 years.
} 
6. In this period, the problems of infrastructure SOEs were addressed through reform, not privatization.

Once again, the Senegalese case is instructive. ${ }^{17}$ In its first and second structural adjustment programs (1980 and 1984), conditionality on privatization dealt with studies of what should and could be sold, the optimal sales methods to be applied, and the creation of a body, the Special Commission on State Disengagement, to guide the process. Only in SAL III (1987) did more demanding conditionality call for divestiture action. In response, in 1987 the Commission published a list of 10 SOEs in which the share of state ownership was to be reduced by the sale of stock. In only two of the ten would a majority stake be transferred; in the other eight it was a matter of further reducing what was already a minority government share. In 1988, the Commission published a second list of 10 additional firms to be divested. However, the government at once removed the two largest firms from this second list, claiming that they required restructuring prior to sale. By the end of 1989 no buyers had come forward for any SOE on either list, or at least no buyers acceptable to the Commission. Regarding privatization, it was clear, or should have been, that Senegal (and a number of other African countries where events moved in a similar manner) was not committed to the reform, and was doing the minimum necessary to placate the IFIs and maintain the dialogue - and the resource flow.

To sum up: By1990, following a decade of donor-supported SOE reform programs, the aggregate performance of the SOE sector in most African countries was not much better, and in some countries worse, than it had been in 1980. Financial burdens, direct or indirect, remained large and damaging. Efficiency levels remained low. Data collection and monitoring efforts too often ended with the departure of the technical assistance personnel that had helped put them in place; they were rarely sustained. Particularly with regard to infrastructure SOEs, one saw in the 1980s persistent repetition in a sequence of both adjustment and investment loans of the same set of policy and structural conditions, indicating that the changes had not been enacted the first, or even the second or the third time called for. The percentage of GDP accounted for by SOEs in SSA did fall somewhat over the decade, due to the declines in subsidies and SOE numbers; but, again, the decrease was less than anticipated.

The donors and IFIs concluded from the experience of the 1980s that the problems of African SOEs were numerous, serious and resistant to change by the means and methods so far applied. Something new was needed. Despite the difficulties encountered in implementing the seemingly less contentious and demanding commercialization approach to SOE reform, and regardless of the widespread reluctance of African governments to accept the rather modest amount of privatization that had been pushed by the IFIs in the 1980s, private sector involvement became the central thrust of overall enterprise reform in the 1990s.

\footnotetext{
${ }^{17}$ Senegal is chosen not because it was a particularly poor performer on SOE reform; on the contrary, the Government of Senegal did more than most SSA regimes to attack the SOE problem. It is simply that there is a comparative wealth of information available on what they tried, and the results.
} 


\section{The 1990s: Paradigm Shift to Privatization/PPI}

\section{Part of a general trend}

Recognition of the poor record of African SOE reform coincided with a major shift in economic thinking that took place in the last quarter of the $20^{\text {th }}$ century (for a global analysis of the shift, see Yergin and Stanislaw: 1998): Away from the Keynesian presumption that the public interest was best served by activist government intervention, and towards (or returning to) the Hayekian notion that "government failure" was a larger problem than "market failure." The electoral victories of Margaret Thatcher and Ronald Reagan; the collapse of the USSR and the revolutions in its satellite states; strong and sustained growth in OECD countries and, in consequence, an exponential increase in private capital available for investment in "emerging markets;" technological innovations in infrastructure production and distribution, especially in telecommunications; an extensive reworking of economic conventional wisdom on the topics of natural monopolies, contestable markets, and the nature and functions of contracts-the emergence and commingling of these trends spread the conviction in the early 1990s that the optimal economic course of action, around the globe, was restraining governments and unleashing markets.

While widespread, the conviction was not universal: Africa remained a taker rather than a maker of policies. Unlike many decision-makers in the ex-communist states and Latin America, most African leaders were not persuaded that the emphasis on private initiative was applicable and appropriate in their settings. But the dire financial circumstances in which they found themselves had increased their reliance on donors in general and the IFIs in particular. African governments felt they had little choice but to go along with policies requested and required by their financiers. They could marginally amend the content and scale and slow the pace of the implementation of the policies, and they could employ passive non-compliance to dilute and delay their impact_—but only in the rarest of cases could they and did they explicitly reject them. Thus, as divestiture and PPI emerged as the central thrusts of IFI-supported SOE reform and conditionality, most if not all borrowing African governments unenthusiastically acquiesced.

The experience of the 1980s had led IFI policy analysts to recognize that a country's privatization prospects varied according to income level and institutional capacity. "In low-income settings...privatization is more difficult to launch, and the chances of a negative outcome are greater." (World Bank: 1992, 29) The same report noted the special difficulties of privatizing infrastructure firms. In these it called for the construction, prior to ownership change, of "a regulatory framework that separates out potentially competitive activities, sets out the tariff regime, establishes universal service goals, develops costminimization targets, and creates a regulatory agency to supervise the established procedures.” (Ibid: 43) The policy prescription was, the poorer the country and the more the SOE in question is a utility operating in a non-competitive environment, the more cautious one should be in moving to privatization.

Despite the caution of theoreticians in the Bank itself, in the period 1989-92, the average annual number of World Bank privatization operations (worldwide) rose rapidly. Note that 
prior to 1992-4, and the coming on line of the numerous and large privatization programs in the ex-communist countries, about half of all World Bank-supported privatization operations were conducted in Africa; roughly 15 African privatization operations were launched each year in this period. Most of these dealt with commercial-manufacturing SOEs, but efforts increased to bring private partners in as managers, and more, in infrastructure firms.

For example, in 1990, the World Bank assisted the Government of Guinea to select a private firm to operate and maintain existing urban water facilities, and bill and collect payments from customers. The project combined a management contract with performance incentives and a long-term lease. Government retained ownership of the assets, responsibility for setting policy and tariffs, and marshalling investment finance and expanding the network. World Bank financing assisted the firm while it tried to raise tariffs to cost-covering levels and improve collections, and provided government with some investment capital to expand the network. This type of partnership operation became a model for infrastructure SOE reform efforts.

So: In the 1980s, privatization had been proposed sparingly by the IFIs, as a last resort for commercial-manufacturing SOEs beyond reasonable hope of rehabilitation. In a short space of time the prescription altered. In the 1990s, donors came to view rehabilitation as legitimate only to the extent that it was a step on the road to liquidation, divestiture or PPI. Previously, four-fifths or more of World Bank SOE reform conditions had focused on restructuring, with one-fifth or less on privatization. These percentages were now substantially reversed. ${ }^{18}$ The notion was discredited that there were some industrial firms of a "strategic" nature in which public ownership and operation was justified. In consequence, all SOEs producing tradable goods became fair game for privatization, the sooner the better. The same clarity and speed could not be applied in the more complex infrastructure cases. ${ }^{19}$ Here, the prescription was to search for a degree of private sector involvement, along the lines of the Guinea water case noted above. By the mid-1990s, the idea of making SOEs function efficiently and effectively under government management was largely abandoned by the IFIs. Privatization and PPI became the order of the day.

Since our main interest is in infrastructure, we concentrate henceforth on PPI. The process started slowly: From 1984-89, 26 developing countries (only one or two in Africa) awarded 72 PPI contracts having a value of \$19 billion US. From 1990 through 2003, PPI exploded: Some 140 different low- and middle-income countries, including almost every African state, awarded 2,731 PPI contracts, attracting an astonishing investment commitments of more than $\$ 800$ billion. (Source of this and other numbers, below: World Bank PPI database) About half of these activities involved ownership or management by

\footnotetext{
${ }^{18}$ Documents and summaries allow one to quantify the aims of World Bank-led SOE reforms in the 1980s. Detailed data on what took place in the 1990s must exist in World Bank project and African country records; but no summations, similar to those cited for the earlier period, are readily available. The effort required to assemble and analyze these data would be considerable and is beyond the scope of the present work. Something of this sort is presently being carried out within the Bank.

${ }^{19}$ Though some tried. This author recalls being asked by an IMF official, in the early 1990s, if it was reasonable to insist that the Government of Kenya turn over its unreformed electricity system to full private ownership within 90 days.
} 
private actors: divestitures, leases, concessions and management contracts. The other half were "greenfield" (i.e., new private) investments to add capacity, for example in electricity generating plants, road, bridge or port building, cellular phone systems, etc.

The sums of private capital invested in infrastructure in emerging markets in this period were in every year at least double, and in some years six, seven or ten times greater than the capital being transferred by "official” sources; i.e., the IFIs and bi-lateral donors. This was very heady stuff. As markets surged, total private flows to PPI in emerging marketsdeveloping countries rose from about $\$ 5$ billion at the end of the 1980 s, to close to $\$ 30$ billion in 1992, to a peak of about $\$ 120$ billion in 1997. At that moment, it seemed as if a revolution had broken out and quickly been won by the private sector rebels.

Countries in Latin America and the East Asia/Pacific were the leading recipients in this process, with countries in Eastern Europe and Central Asia not far behind.

\section{PPI in Africa}

As of 2005, in half of African countries, the water, fixed-line telephone, railways, airlines and petroleum products distribution sectors are still state-owned and operated companies; the percentage rises to two-thirds for electricity generation, transmission and distribution. (World Bank: 2005, 13) PPI started much more slowly in Sub-Saharan Africa; only 25 such operations came on line (were "financially closed") from 1991 through 1993. However, the number jumped to 70 in the period 1994-97. After 1997, capital flows and PPI projects declined in most parts of the world, but infrastructure investors sustained their interest in Africa for some time-closing an additional 140 contracts from 1998-2003. (More recently, African PPI appears to be trailing off; only 16 projects closed in SSA in 2003, the last year for which data are available.) The point is that the timing of PPI in Africa differed from other parts of the world.

Nonetheless, of the 2,731 PPI contracts concluded in 1990-2003, only 224 were in SSA, scattered over 47 different countries. Investments in these African PPI operations totaled an impressive $\$ 33.4$ billion US. PPI in SSA in these years accounted for about 40 percent of all infrastructure investment, with government-generated and official investment splitting the remainder. Still, while important in absolute terms, investment in Africa represented only about four percent of the worldwide PPI total_—and the most revealing fact is that almost half of all investment in Africa went to South Africa alone. The forty-six other participating SSA countries have so far garnered a very modest 2 percent of the PPI investment bonanza. 
TABLE 1

PPI PROJECTS BY REGION \& INVESTMENT AMOUNTS, 1990-2003

\begin{tabular}{|l|c|c|c|}
\hline REGION & COUNTRIES & $\underline{\text { PROJECTS }}$ & $\underline{\underline{\text { INVESTMENTS \$ }}}$ \\
\cline { 2 - 4 } & & & $\underline{\text { in US billions) }}$ \\
\hline E. Asia/Pacific & 18 & 524 & 187.7 \\
\hline Europe/Cent. Asia & 26 & 1008 & 118.6 \\
\hline Lat. America/Carib. & 28 & 76 & 378.8 \\
\hline Mid. East/No. Africa & 14 & 198 & 38.3 \\
\hline South Asia & 6 & 224 & 45.0 \\
\hline Africa & 47 & $(25)$ & $\mathbf{3 3 . 4}$ \\
( South Africa alone) & & & $\mathbf{1 6 . 0 )}$ \\
\hline Totals & 139 & 2,731 & $\mathbf{8 0 1 . 0}$ \\
\hline
\end{tabular}

Source: Calculated from World Bank, Private Participation in Infrastructure (PPI) database.

TABLE 2:

PPI in S-S AFRICA, 1990-2003, by SECTOR \& INVESTMENT AMOUNT (US \$ billions)

\begin{tabular}{|l|c|c|}
\hline SECTOR & AMOUNT & PERCENTAGE \\
\cline { 2 - 3 } Energy & 7,375 & 22.1 \\
\hline Telecommunications & 21,724 & 65.0 \\
\hline Transport & 4,081 & 12.2 \\
\hline Water \& Sewerage & 230 & 0.7 \\
\hline \multicolumn{1}{|c|}{ TOTAL } & 33,410 & 100.0 \\
\hline
\end{tabular}

Source: Calculated from World Bank PPI Database.

TABLE 3:

PPI in S-S AFRICA 1990-2003, by SECTOR \& TYPE of PPI OPERATION

\begin{tabular}{|c|c|c|c|c|c|}
\hline SECTOR & " GREENFIELD & "DIVESTITURE & בCONCESSION & MC/LC* & TOTALS \\
\hline Energy & 22 ops, $44.9 \%$ & 5 ops, $\quad 10.2 \%$ & 12 ops, $24.5 \%$ & 10 ops, $20.4 \%$ & $49,100 \%$ \\
\hline Telecomm & 95 ops, $84.8 \%$ & 15 ops, $13.4 \%$ & 0 ops, & 2 ops, $1.8 \%$ & $112,100 \%$ \\
\hline Transport & 13 ops, $26.5 \%$ & 3 ops, $6.1 \%$ & 22 ops, $44.9 \%$ & 11 ops, $22.4 \%$ & $49,100 \%$ \\
\hline $\begin{array}{l}\text { Water \& } \\
\text { Sewerage }\end{array}$ & 2 ops, $14.3 \%$ & 0 ops, $\quad 0 \%$ & 2 ops, $14.3 \%$ & 10 ops, $71.4 \%$ & $14,100 \%$ \\
\hline $\begin{array}{l}\text { Total \# PPI } \\
\text { by type }\end{array}$ & 132, $58.9 \%$ & $23,10.3 \%$ & $36,16.1 \%$ & $33,14.7 \%$ & 224 \\
\hline
\end{tabular}

Source: Calculated from World Bank PPI Database. $\quad\left({ }^{*}\right.$ MC/LC $=$ managements contracts and/or lease contracts.) 
TABLE 4:

TOP FIVE RECEIVERS OF PPI INVESTMENT IN S-S AFRICA, 1990-2003

\begin{tabular}{|c|c|c|}
\hline COUNTRY & PPI INVESTMENT，\$ BNs & $\begin{array}{l}\frac{\text { \% TOTAL PPI }}{\text { INVESTMENT IN SSA }} \\
\end{array}$ \\
\hline South Africa & 16.0 & 47.9 \\
\hline Nigeria & 3.1 & 9.3 \\
\hline Mozambique & 2.5 & 7.5 \\
\hline Cote d'Ivoire & 1.4 & 4.2 \\
\hline Tanzania & 0.9 & 2.8 \\
\hline Total & 23.9 & 71.7 \\
\hline
\end{tabular}

Source: Calculated from World Bank PPI Database.

Telecommunications accounts for half of all PPI operations and almost 2/3 of PPI investment in SSA (more than half of it going to South Africa alone). Energy is a distant second, transport farther back, and PPI in African water and sewerage is comparatively miniscule, both in project number and investment amount. Greenfield investments have been by far the most frequent form of African PPI, followed by concessions and management or lease contracts. More than half of all investment generated has been in greenfield operations (which assist in reform of a sector, but are only indirectly SOE reform measures). Divestiture operations rank second.

The type of PPI favored varies by sector. Greenfield investments are the dominant method in telecommunications, and to a lesser extent, in energy; management- and lease-contracts in water and sewerage, and concessions in African transport. ${ }^{20}$ Divestiture - the turning over of a major equity stake to a private operator-has rarely been applied in African infrastructure, except in telecommunications.

The upshot of all these data is as follows: SSA participated in the PPI boom of the past 15 years, but at a slower pace and to a lesser extent than other parts of the world. The bulk of regional PPI investment that has occurred has gone to South Africa; the next most attractive African countries lag far behind. (see Table 4) There are very many SSA countries that have concluded but one or two PPI projects, raising a few million dollars. Nonetheless, SSA did a bit better than other regions in sustaining investor interest following the post-Asian crisis declines in investment. Relative to the size of African economies, and the total amount of investment raised from all sources, PPI is of great importance-especially in light of the existing and likely future magnitudes of official flows.

Most of this PPI activity has been actively sponsored or endorsed by the IFIs. Some investors have entered on their own, and some African governments have sought PPI without IFI stimulation or assistance, especially in the increasingly competitive, lower risk, telecommunications sector. What is known concerning the results of this altered reform strategy?

\footnotetext{
${ }^{20}$ For a discussion of the methods applied in each sector, see Gökgür, 2004.
} 


\section{Results in general}

Starting at the end of the 1980s and gathering strength through the 1990s, many studies looked at the results of privatization, attempting to measure the financial, economic, distributive and social welfare effects. A number of these, particularly those looking at infrastructure privatization, devised new methods to assess privatization's impact on the range of stakeholders affected by the transaction-government, the new private owners, workers, consumers, and even competitors. The most sophisticated of these analyses strove to determine the extent to which the transaction added to or subtracted from the country's general economic welfare, and how the gains or losses were distributed among the relevant actors. To do this required the establishment of a "counterfactual;" that is, as precise as possible an estimate of what would have happened had the firm remained under state control. ${ }^{21}$ The findings of most of the empirical studies, including the welfare studies, were generally-though not entirely, and, as we shall see, not decisively-encouraging to supporters of privatization and PPI.

First, the positive aspects: Post-sale, in the main and on average, firms tend to improve their profitability, efficiency (as measured by labor productivity) and returns to shareholders. Many infrastructure firms submitted to PPI show improved finances, a much better quality and a larger quantity of service. Many show network expansion at a rate much higher than that achieved while the firm was under public management. The number of employees tends to decline (which largely explains the increases in productivity). But in most countries, and except in railroads, the overall number of infrastructure workers dismissed due to privatization is relatively small, and not a major contributor to general unemployment levels. Post-sale, prices tend to decline for telephone services. The price record is mixed in energy, and shows general (not universal) increases in transport and water and sewerage. Government finances tend to improve as subsidies decline. The relatively few studies estimating changes in welfare mainly record positive results, with surprisingly few instances of increases in inequity due to the reform. In sum, technical/economic assessments of privatization broadly conclude that the benefits outweigh the costs.

Now the not-so-good news: The number of rigorous studies remains low; we do not possess sufficient information to reach a definitive conclusion regarding PPI's effects. ${ }^{22}$ Moreover, the general superiority of privatization/PPI to state control is not conclusively proved by showing that the number of cases with positive outcomes is larger than the number of negative instances. Most of the positive studies do reveal some sub-optimal outcomes, for at least some set of stakeholders at some point in time. Several case studies do reveal poor and unanticipated general outcomes, and a few describe investor withdrawal, project cancellation, and public protest, in some cases violent. These are the cases seized upon by the public and by opponents of the process. It might be that the total

\footnotetext{
${ }^{21}$ See, for a sample of the best and most rigorous assessments, Galal, et al., 1994; Newbery and Pollitt, 1997; Chisari et al., 1999; and Mackenzie and Mookherjee, 2003.

${ }^{22}$ On the other hand, the superior performance of privatized as opposed to state-owned firms in manufacturing, commercial and industrial — that is, non-infrastructure- sectors seems very well established.
} 
costs of the negative cases are greater than the total benefits of the positive ones. In the absence of an aggregated study of the counterfactual, we do not know.

A second concern is that the highly positive PPI results come mainly from cases in high or middle income countries. For example, the bulk of studies showing combined technical, financial and welfare improvements from PPI come from Latin America. African policymakers and observers are not convinced that the same results could be obtained in their poorer, institutionally weaker countries-and if they were tempted to follow the Latin American model, recent PPI reversals and ensuing, related political turmoil in some countries in that region (e.g., Bolivia) may have dissuaded them.

\section{PPI results in Sub-Saharan Africa}

Until recently, there have been fewer assessments of privatization/PPI in SSA, and those undertaken were, due to data problems, forced to use less sophisticated methodologies ${ }^{23}$ than those applied in Latin America. In her recent review of the results of PPI in SSA, Gökgür found positive economic, financial, quality, quantity and distributive outcomes from PPI in telecommunications in Cote d'Ivoire, Ghana, Senegal and Uganda-but noted that the greater the degree of competition enhancement simultaneous with the PPI event, the better the overall results. (Gökgür: 1994, 20-22) ${ }^{24}$ Gökgür also called attention to the absence of similar rigorous cross country assessments in the other three infrastructure sectors.

There has been some careful work carried out on PPI in the water sector in a few SSA countries (Ménard and Clarke: 2002). The conclusions are that performance improved under PPI, compared to what reasonably could have been expected to happen under continued public management. However, the gains were less than expected by all the parties (government, the investor, the supporting World Bank), and they came at a much slower than anticipated pace. The problem of non- or slow and partial payment of water bills by government consumers was not solved under the PPI arrangements, neither in Guinea, nor Cote d’Ivoire nor Senegal.

Wallsten (1999) examined econometrically the effects of privatization, competition enhancement and regulation in telecommunications reform in 30 countries, half of them in Africa, the rest in Latin America. Enhanced competition produces the clearest, most positive effects. Ownership change by itself "does not appear to generate many benefits," but does so when combined with separate and independent regulation. These are summary conclusions, not disaggregated by region. Wallsten notes that “....the finding that privatization is negatively correlated with the number of main lines....could arise because

\footnotetext{
${ }^{23}$ In their book on African privatization, Campbell-White and Bhatia (1998: 125) noted that "Monitoring and evaluation have largely been ignored; hence the paucity of data on - and the difficulty of judging - the progress and impact of privatization to date.”

${ }^{24}$ Indeed, analysts of privatization have long had trouble distinguishing between the post-sale effects of ownership change and the effects of concurrent policy change and competition enhancement. Many economists see competition as a more important determinant of outcomes than ownership per se. This has led critics to argue that privatization is secondary or even unnecessary; "all" that is needed is increased competition.
} 
countries are more likely to privatize their incumbent telecom provider when service is poor...." (14) Thus, it may not be that privatization caused performance to weaken, as suggested by the regression, but rather that the weakest telecommunication firms were the ones to be privatized.

Regarding energy, Gökgür's survey concludes that "Cote d'Ivoire is the only country where efficiency gains after private participation in electricity were measured and reported.” (Gökgür: 2004, 18) There are, however, at least two other (not formally published) assessments of PPI in electricity, in Gabon and Namibia (PPIAF: 2002a and 2002b). The Gabon report is highly positive; it notes consistent improvement in electricity service quality over the life of the concession contract. Despite a reduction in tariffs, the energy provider self-financed all contractually required repair and expansion investments, and met or exceeded all targets of network extension to small towns and rural areas. Following a confrontation in 1999, government agreed to timely payments of all arrears and current utility obligations, and has lived up to the bargain. This is seen as a major factor in this operation's success. (WorldBank/PPIAF: 2002a)

The Namibian case is quite revealing, both for it's recounting of similarly impressive technical and financial gains, and for its depiction of the intrusion and importance of sociopolitical factors in the ultimate fate of the operation. Under a 5 year management contract to provide service to a rural, previously underserved region, the private operator doubled the number of customers, held employment steady, reduced tariffs for the smallest and presumably poorest consumers, reduced system losses from 45 to 7 percent, and effected numerous and substantial quality improvements. (World Bank/PPIAF: 2002b) Its reward: The contract was not renewed and the national SOE energy provider, that had not shown interest in bidding for the contract the first time around, lobbied hard to discredit the private provider and obtain the assignment-which it did. The explanation is complex, having to do with the failure of the original contract to deal with the concerns of the local government authorities in the region being served, who then opposed renewal of the contract; along with the perception of the national energy SOE that it was being shown up by the private provider. The case writers' conclusions were that stakeholders valued the improved service but thought it was "just management;" i.e., that anyone could emulate the private provider's success. They also reasoned that "private sector participation is not just about infrastructure investment," and that somehow the PPI provider must "avoid politics but pay attention to politics.” (Ibid.: 35-36)

An early draft of a review of seven African PPI $\operatorname{cases}^{25}$ states that none of the contracts examined have produced levels of service comparable to industrialized country settings, and all have encountered significant problems, either financial or political or, frequently, both. Nonetheless, as with most technical examinations, this study concludes that the results are "better compared to what the outcomes would have been without private sector contracts.” (Castalia Strategic Advisors: 2005, 1) The authors argue that excessively high expectations and inappropriate measurement criteria have been applied to African PPI

\footnotetext{
${ }^{25}$ Concessions, lease and management contracts in Cote d'Ivoire (water), Guinea (water), Gabon (electricity and water), Malawi (electricity), Mozambique (water), Senegal (water) and Tanzania (electricity).
} 
efforts, by both donors and governments. The use of more reasonable, less ambitious evaluation criteria shows more positive results.

However, if a fair number of arguable positive case studies of PPI do not add up to a solid conclusion in the rest of the world, a much smaller number of case studies is even less convincing in Africa. An additional way to measure the impact of PPI in Africa is by looking at the number and size of contracts that have been cancelled or classed as "distressed;" i.e., "projects where the government or the operator has either requested contract termination or are in international arbitration.” (PPI Database, Glossary) Table 5 presents these data, through 2003, comparing Africa to other regions.

Table 5

Cancelled and Distressed PPI Projects, 1990-2003 By Region and Sector

\begin{tabular}{|l|c|c|c|c|c|}
\hline \multicolumn{1}{|c|}{ Region } & Energy & Telecomm & Transport & $\begin{array}{c}\text { Water \& } \\
\text { Sewerage }\end{array}$ & Totals* \\
\hline E. Asia/Pacific & 10 & 5 & 15 & 6 & $\begin{array}{c}36 \\
5 \% ; 9 \%\end{array}$ \\
\hline $\begin{array}{l}\text { Europe/Cent. } \\
\text { Asia }\end{array}$ & 3 & 7 & 2 & 0 & $\begin{array}{c}12 \\
2 \% ; 3 \%\end{array}$ \\
\hline $\begin{array}{l}\text { Lat. } \\
\text { America/Carib. }\end{array}$ & 41 & 1 & 24 & 8 & $\begin{array}{c}74 \\
7 \% ; 12 \%\end{array}$ \\
\hline $\begin{array}{l}\text { Mid. East/No. } \\
\text { Africa }\end{array}$ & 0 & 2 & 1 & 0 & $\begin{array}{c}3 \\
2 \% ; 2 \%\end{array}$ \\
\hline South Asia & 3 & 1 & 1 & 0 & $\begin{array}{c}5 \\
3 \% ; 2 \%\end{array}$ \\
\hline Africa & 3 & 5 & 3 & 1 & $\begin{array}{c}12 \\
5 \% ; \\
0.6 \%\end{array}$ \\
\hline \multicolumn{1}{c|}{ Totals } & 60 & 21 & 46 & 15 & 142 \\
\hline
\end{tabular}

Source: World Bank PPI Database. * Percentages below "Totals" in the last column refer to percent of projects cancelled or distressed and percent of total investment in the region involved in such operations.

By this reckoning, Africa is one percentage point above the mean in terms of proportion of PPI projects in difficulty. The difference is small, and the troubled African operations are quite modest in size, affecting only a tiny amount of total investment.

However, there is reason to believe that these numbers underestimate the problems that PPI is currently facing in SSA. First, the table does not show lease-, management-contracts and concessions that were not cancelled, nor officially called into question, but were not renewed after their initial period expired — as in the Namibian example given above and the non-renewal (after a one-year extension) of the water lease in Guinea. The least that one can say in such cases is that sustainability was not attained ${ }^{26}$ unless it can be shown that

\footnotetext{
${ }^{26}$ Though this may be a matter of differing expectations on the part of governments, that are said to see management contracts as a means of improving public sector performance, and donors — who regard such
} 
the management contractors left behind a set of trained and competent local replacements. Second, a fair amount of PPI activity in Africa was initiated after 2000. Normally, problems serious enough to warrant the distressed label take time to arise. Perhaps the rate of problems accelerated in 2004, a period not yet recorded in the PPI database? And indeed, a number of World Bank infrastructure personnel working on Africa report a recent increase in troubled PPI projects. Third, the definition of "distress" does not cover projects where one party or the other is seeking a renegotiation of the contract, but has not yet escalated the conflict to the level of cancellation or a request for international arbitration. Again, World Bank infrastructure personnel note an increase in such cases. A snapshot of PPI in African energy (Benoit: 2005) notes that a number of operations originally contracted as concessions-giving a large amount of control and associated risk to the private provider - are presently unsatisfying to one or both of the contracting parties. A number are likely to be renegotiated into lower risk, and lower control, management contracts; in some there is a risk of total termination.

Similar concerns are expressed in the water sector. There has recently been a non-renewal of a management contract, private provider withdrawal and a cancellation of a lease in Uganda, Mozambique and Tanzania respectively. The most recent and dramatic instance was in Tanzania where, in late May 2005, the Government cancelled the water sector lease, called the performance bond, and summarily deported three expatriate managers-whose firm is now considering legal action. The least that one can say is that all is not well with the PPI approach in Africa.

\section{Conclusions}

We have reviewed a few of the few assessments of African PPI initiatives. The good news is that many more are presently underway and a larger body of findings should soon be available. ${ }^{27}$ The existing case studies tend to look at technical successes; few detailed assessments have been made of failures, such as electricity PPI in Senegal, or the water cases in Mozambique and Tanzania. These are, to repeat, presently under review; the recent spate of problem cases is being tabulated and assessed in detail.

One must also account for the hostility towards PPI initiatives, successful or not, on the part of many — but by no means all—African leaders, intellectuals, journalists, and the local and international NGOs that observe and comment on economic programs. We have already noted the results of the survey showing the low level of privatization's popularity in many African states. A newspaper editorial from Zambia gives the flavor of the dissatisfaction:

contracts as the first step on the route to greater private sector participation and control. Thus, governments may be less upset by non-renewal than donors. This view is presented in Castalia, op. cit.

${ }^{27}$ A preliminary draft of the first of a set of studies in process (Gökgür and Jones: 2005), reviewing the experience with water PPI in Mozambique, again concludes that technical performance greatly improved under the contract—but that many consumers nonetheless feel they are paying more for largely unimproved service. 
........despite having liberalized its markets, as dictated by the IMF and the World Bank, Zambia has still not started benefiting from it......Why should we privatize Zambia National Commercial Bank, Zesco Limited (electricity) and Zamtel (telecommunications) simply because the IMF and the World Bank want us to do so even when the great majority of Zambians are opposed to it because they believe it is not in their best interest? (Editorial in the Lusaka Post: 11.28.02)

Less stridently and more recently, a similar view is expressed in an editorial from Tanzania:

TTCL (telecom) is beset with staff-management wrangling, Tanesco's (electricity) performance has not improved considerably, and City Water-the termination of whose contract has triggered a crisis - didn't meet the expectations of water consumers.

It is apparent that there are weaknesses in the way privatization and joint venture schemes are handled, which ought to be addressed. For we surely must have learnt that foreigners are not miracle workers and that our country has a crop of managers and technical cadre that can do wonders, if availed a sufficiently conducive environment. (Editorial in the Dar es Salaam Sunday Observer, May 22, 2005)

Clearly, infrastructure and financial sector privatizations have been the prime targets for popular and official criticism. The larger amount of privatization carried out in African commercial and manufacturing sectors has not come in for nearly as much censure. One problem in infrastructure is the perceived loss of sovereignty; i.e., the turning-over of what are seen as vital and valuable national assets to multinational firms (or worse, to firms based in neighboring countries; e.g., the sale of Zambian firms to South Africans). A second part of the problem is a widespread, though questionable, belief that privatization inevitably results in steep increases in utility prices post-sale_-leading to the claim that the poor cannot or can no longer afford essential services. ${ }^{28}$ Third, there is suspicion that many PPI privatization and concession transactions have been tainted by fraud and corruption, or just excessive aggressiveness on the part of the private provider. That is, that the private bidders have colluded to reduce the price paid for a firm or concession; that they manage to get their foot in the door by contracting to provide a service at price $\mathrm{x}$, but once in office claim that undisclosed vital information forces them to renegotiate the agreement; ${ }^{29}$ that politicians have taken bribes to favor one particular bidder or to rig the contractual or regulatory rules in favor of a private firm or owner; or more broadly, that many

\footnotetext{
${ }^{28}$ The argument is dubious: Recall that the African poor rarely have access to formal electricity or water networks, and they tend to pay much higher unit prices for these services, or substitutes for these services (e.g., kerosene or batteries), than those connected. Price increases in the formal systems normally affect the relatively affluent. On the other hand, as networks expand and offer access to previously unserved clients, connection fees can be very large; one can make a good argument that subsidization of these fees is justified on poverty reduction grounds. (see Estache, Foster and Wodon: 2002)

${ }^{29}$ This is a two-way street: No doubt, some private providers have employed such tactics. On the other hand, some governments have refused, for purely political reasons, to honor the commitments they agreed to in contracts. A major hindrance to the construction of credible PPI contracts is the paucity and poor quality of historical technical and financial data on the firms in question. The absence of benchmarks allows private contractors to claim that wrong or missing information justifies renegotiation, and governments to claim that the private provider is not living up to expectations.
} 
governments in Africa lack the skills and resources to negotiate well with multinational or even domestic private firms in such a way as to protect the public interest during the sale, or to create and sustain competent, independent regulatory institutions post-sale.

In Africa, as elsewhere, the basic political conundrum of privatization (not just in infrastructure) is as follows: PPI's benefits for consumers at large tend to be dispersed among amorphous, unorganized segments of the public. The benefits are small for each affected consumer. They occur in the medium term, or at least they accrue to a significant size in the medium term. A sustained decline by $5-10 \%$ in average electricity tariffs, for example, is in aggregate a substantial and worthwhile gain for any economy. And increased disposable income by a few currency units a billing period is no doubt welcome to the great mass of consumers. But gains of this nature do not move masses of consumers to mobilize politically in favor of the policy, much less the reforming regime. In any case, some consumers, particularly poor ones, probably do not associate any gains from reduced tariffs (to the extent they even perceive them ${ }^{30}$ ) as having anything to do with privatization of the service. Modest average real price declines thrill economists, but not voters.

The costs of privatization, in contrast, are concentrated among a visible, vocal and urbanized few-dismissed workers, represented by powerful public sector unions; bureaucrats in supervisory ministries that lose their authority, perks and perhaps even raison d'etre; managers and board members of SOEs removed pre- or post-sale, upperincome consumers about to lose a service long-furnished at a subsidized price. Though the sum of their welfare losses are, presumably, much less than the aggregate gain, these actors possess "voice" and access to power; they can and do make their needs and views known. They are motivated to do so because the losses for each affected individual are comparatively large, and they occur in the very short term, indeed, in the case of affected workers, often before the completion of the transaction. Losses of comparatively large magnitude, among stakeholders of this nature, typically result in protest, direct political action, or equally (if not more) effective bureaucratic delay and misdirection. The reality is that it is easier to mobilize protest against losses than to engender gratitude for gains; and the gratitude created by the awarding of any gain is far less politically potent than the protest generated by the imposition of an equivalent loss.

One can argue that much anti-privatization sentiment in Africa stems from a lack of understanding or appreciation of what PPI has accomplished, combined with a pronounced tendency to forget both the poor past performance of state-owned infrastructure firms, and the very poor track record of performance improvement attempts that did not involve the private sector. While technically accurate, such an argument is politically ineffective.

All this leaves African policy makers, and those that wish to assist them, facing an acute problem: Both the quantity and quality of African infrastructure services are sub-optimal, and have been for some time. Past reform tactics based on an evolutionary approach did not produce the needed and anticipated results. Revised tactics based on privatization and PPI have not been as widely adopted as anticipated, nor have they generated the massive

\footnotetext{
${ }^{30}$ If, as sometimes happens, the rate of inflation spikes in the post-contract period, the average consumer pays more in current terms, and the gain could only be perceived when a constant currency value is used.
} 
resources and changes hoped for, nor have they been widely accepted as beneficial by many in the African public (though it must be noted that public perceptions of PPI are positive in a number of specific cases where service improvements quickly occurred; e.g., water in Senegal and electricity in Gabon.).

So: the need to repair, modernize and expand African infrastructure networks remains very great. The financial resources required for this task must come from governments, official sources, and, increasingly, from private capital markets. The two approaches on which reform hopes have been based have both proven deficient, though in different ways. The revised tactics require further revision. The search for mechanisms that combine private capital and expertise with socially acceptable management and delivery must be renewed.

It is beyond the scope of this study to state in detail what the next phase of reform could and should look like. Nonetheless, one can offer some guidance on what it should not be. In light of the difficulties of making PPI work effectively in Africa, one might make a case for a return to the SOE model. That idea is that the experience of the last three decades has taught both African governments and assisting donors to be wary and vigilant, and that they now possess improved management and financial techniques for monitoring firm performance and enforcing financial discipline and quality standards.

However, the experience of the 1970s and 80s, recounted in this paper, leads one to be very wary of any simple return to the commercialization of state owned and operated entities. Why?

- Returning to government ownership and operation means returning to a heavy reliance on government and official financing. In Africa, these sources have not provided, and even if drastically expanded, will not provide the capital sums needed for network rehabilitation and expansion.

- Thus, if Africa infrastructure is to be renewed and enlarged to meet demand, private money will be required. This will likely require passing some measure of control and management to the private provider.

- Moreover, it is not at all clear just why and how a return to the SOE approach would work. Where is the concrete evidence that African governments can resist the political pressures that in the past led them to allow politics to trump economics when it came to infrastructure payment and pricing issues? Just how will the mistakes of the past be overcome? Unless one can provide specific answers to these questions there is a risk that the error of the 1990s—assuming that privatization had to result in better performance than state ownership and operation - will be repeated, this time in reverse.

- Finally, one must note that the World Bank (and other official lenders) has a strong incentive to restart and ramp up lending to infrastructure SOEs in Africa, over and above its recognition of the limitations of the PPI approach. That is, as more middle-income countries tap private $^{31}$ capital markets for their

\footnotetext{
${ }^{31}$ For example, in 9.04 Citigroup concluded the first private loan, of $\$ 300$ million, to the Russia State Railways Corporation, an SOE, following its successful corporatization and earning of a credit rating by an international rating firm.
} 
infrastructure investment needs, the Bank increasingly becomes a lender to lowincome states. In its desire and need to sustain its role as a capital-transferring institution, and not just an advisory agency, the Bank sees a renewed role for itself in infrastructure reform. Well and good. But in the past, the desire and need to lend have sometimes trumped critical acumen, and led to the approval or continuation of sub-optimal operations. How will this be guarded against?

In sum, the findings of recent studies in Africa suggest that PPI should not be jettisoned. Rather, the more productive path is to recognize the limitations of the approach, and to work harder at creating the conditions needed to make it function effectively. This will entail, as many have recognized, an end to the view that public and private infrastructure provision is a dichotomy - a case of either-or, one or the other — and a better appreciation of the extent to which the performance of each is dependent on the competence of the other. In other words, for the private sector to perform well, public sector capacity must be enhanced. Moreover, proposed tactics of reform should fit more closely with the expectations and sentiments of the affected government and population. This broader approach implies a reduction in both the scope and especially the planned speed of operations. Improving infrastructure performance is a long-term matter.

Adoption of this revised strategy should aid the acceptance and ease the implementation of infrastructure reform. But it also has costs: African infrastructure networks need expansion now, not years from now. Settling for the more cautious, politically palatable and socially acceptable PPI forms-for example, management contracts as opposed to concessions or divestitures - will not solve the capital shortage problem. Moreover, and somewhat paradoxically, the more acceptable management and lease contracts place heavy demands on governments, in terms of designing, negotiating, evaluating and enforcing them. As the Castalia study notes: "the more limited the private sector involvement, the more complex is the interface with the government." $(2005,1)$ And the creation and sustaining of government capacity is precisely the point where both the state-led and the PPI approaches have been most deficient.

The bottom line is that Africa has huge infrastructure needs that, for various reasons, are not being addressed the only way that is financially possible: with private money. 


\section{REFERENCES}

Algérie Presse Service. 1975. “L’Industrialisation: remède unique aux problèmes de sousdéveloppement. » Alger: 1975.

Benoit, Philippe. 2005. “A Snapshot of PPI in Sub-Saharan Africa’s Power Sector.” World Bank, Africa Energy Department, draft, unpublished note, January.

Bovet, David. 1985. "Financial Aspects of Public Enterprises in Sub-Saharan Africa.” Unpublished paper submitted to the World Bank.

Campbell-White, Oliver, and Anita Bhatia. 1998. Privatization in Africa. Washington, DC: World Bank.

Castalia Strategic Advisors. 2005. "Experience with Private Participation Sub-Saharan African Infrastructure: What are the Lessons for Future Policy?” Draft unpublished report to the Africa Infrastructure Department of the World Bank.

Chisari, Omar, Antonio Estache, and Carlos Romero. 1999. "Winners and Losers from the Privatization and Regulation of Utilities: Lessons from a General Equilibrium Model of Argentina.” World Bank Research Observer. Vol. 13, No. 2.

Estache, Antonio, Vivien Foster, and Quentin Wodon. 2002. Accounting for Poverty in Infrastructure Reform. Washington, D.C. The World Bank Institute of Development Studies.

Galal, Ahmed, et al. 1994. Welfare Consequences of Selling Public Enterprises. Washington, DC: World Bank.

Gökgür, Nilgün, 2004. “Assessing Trends and Outcomes of Private Participation in Infrastructure in Sub-Saharan Africa.” Unpublished paper, Boston Institute for Developing Economies (BIDE).

Gökgür, Nilgün, and Leroy Jones. 2005. “Mozambique Water Sector.” Draft unpublished report to the Africa Infrastructure Department of the World Bank.

Government of Kenya. 1965. African Socialism and its Application to Planning in Kenya. Nairobi: Government Printer.

Government of Kenya. 1982. Report and Recommendations of the Working Party on Government Expenditures. Nairobi: Government Printer. 
Grosh, Barbara, and Rwekaza S. Mukandala. 1994. State-Owned Enterprises in Africa. Boulder, Colorado: Lynne Reiner Publishers.

Killick, Tony. 1981. Policy Economics. London: Heineman.

McKenzie, David and Dilip Mookherjee. 2003. "Distributive Impact of Privatization in Latin America: An Overview of Evidence from Four Countries." Economia, vol. 3, no. 2, Spring, pp. 161-218.

Ménard, Claude and George R. G. Clarke. 2002. "A Transitory Regime: Water Supply in Conakry, Guinea," in Mary Shirley, editor, Thirsting for Efficiency: The Economics and Politics of Urban Water System Reform. Washington, DC: The World Bank, 2002.

Msambichaka, L. A., and M. S. D. Bagachwa. 1984. "Public Sector Enterprises in Tanzania: Problems and Constraints.” Viertel Jahres Berichte [journal of the German Freiderich Ebert Foundation] (December, 1984).

Nellis, John. 1986. Public Enterprises in Sub-Saharan Africa. Washington, DC: World Bank Discussion Paper No. 1.

Nellis, John. 1988. "The Institutional Framework: Organization, Management and Supervision of Tanzanian Parastatals.” Unpublished chapter in World Bank report on Tanzanian public enterprises.

Nellis, John. 1989a. Les Contrats de Plan et leur rôle dans l'amélioration de la performance des entreprises publiques. Washington, DC: World Bank Discussion Paper No. 48F.

Nellis, John. 1989b. "Public Enterprise Reform in Adjustment Lending." Washington, DC: World Bank Working Papers, WPS 223.

Nellis, John. 2003. "Privatization in Latin America.” Washington, DC: Center for Global Development, Working Paper No. 31.

Newbery, D.M., and Pollitt, M.G. 1997. "The Restructuring and Privatisation of Britain's CEGB—Was it Worth it?” Journal of Industrial Economics, 45(3): 269-303.

Shirley, Mary and John Nellis. 1992. Public Enterprise Reform: Lessons of Experience. Washington, DC: World Bank, Economic Development Institute, Studies in Development series.

Tanzania Audit Corporation. 1986. Tanzania Audit Corporation $17^{\text {th }}$ Annual Report. Dar es Salaam, Tanzania: Government Printer. 
Wallsten, Scott. 1999. “An Empirical Analysis of Competition, Privatization and Regulation in Africa and Latin America." Washington, DC: World Bank Working Paper, WPS 2136.

World Bank. 1985. "Les politiques de transport en Afrique francophone au Sud du Sahara: Problèmes et Choix.” Washington, DC: Economic Development Institute, World Bank.

World Bank. 1991. Restructuring Economies in Distress: Policy Reforms and the World Bank. Washington, DC: The World Bank.

World Bank. 1992. Privatization: Lessons of Experience. Washington, DC: World Bank.

World Bank/Private Provision of Infrastructure Advisory Facility (PPIAF). 2002a. "Emerging Lessons in Private Provision of Infrastructure Services in Rural Areas: Water and Electricity Services in Gabon.” London: Environmental Resources Management Group, unpublished report.

World Bank/PPIAF. 2002b. "Northern Electricity Distribution Service in Northern Namibia: A Case Study in the Private Provision of Rural Infrastructure.” Econ One Research, Inc., and EMCON Consulting, unpublished report.

World Bank. 2005. "Privatization: Trends and Recent Developments.” Draft Working Paper. Investment Climate Department.

Yergin, Daniel, and Joseph Stanislaw. 1998. The Commanding Heights. New York: Simon and Schuster. 